\title{
Investigation of Digital Game Addiction Levels of High School Students
}

\author{
Research Article
}

\section{Esra Bayrak AYAS ${ }^{1}$}

${ }^{1}$ Adıyaman University, High School of Physical Education and Sports, Department of Physical Education Teaching, Adıyaman, Turkey ORCID: 0000-0001-8153-2313

To cite this article: Ayas, E. B. (2020). Investigation of Digital Game Addiction Levels of High School Students, International Online Journal of Educational Sciences, 12(3), 81-91.

\begin{abstract}
ARTICLE INFO
Article History:

Received: 11.01.2020

Available online:

24.06.2020

ABSTRACT

Technological developments that have influenced every moment of our lives have started to be effective in game concept and digital games have been replaced by traditional games. As a result of these developments, it was aimed to determine the levels of digital game addiction of students at high school level and to investigate whether various variables are effective on addiction. A total of 277 students participated in the study based on volunteering concept. Digital game addiction scale developed by hazar and hazar (2019) was used in the research. It was understood that the students who participated in the research had high levels of digital game addiction. It was determined that age factor had no effect on digital game addiction level. However, it has been observed that there are differences in gender, time zone and material variables used on digital game addiction.
\end{abstract}

(C) 2020 IOJES. All rights reserved

Keywords:

Game, Digital game, Digital game addiction.

\section{Introduction}

The concept of play, which has a history as old as the birth of human beings, has contributed significantly to the formation of the culture and civilizations that the society has. Therefore, the meanings attributed to the game were reflected in that culture and civilization. However, the increasing urbanization activities along with the rapidly developing technological developments have affected the game concept. This increase negatively affected the traditional playgrounds and restricted the game and entertainment area of individuals of all ages. On the other hand, the computer and internet that facilitate every area of life, become an entertainment tool and have caused an increase in interest in digital games (Gentile 2009, Rideout et al. 2010). The fact that young people follow the technological developments closely has caused them to show excessive interest in digital games. This has transformed digital games into popular culture images among

${ }^{1}$ Corresponding author's address: High School of Physical Education and Sports, Department of Physical Education Teaching

Telephone: +9 (0416) 223 3800-2884

e-mail: ebayrak@adiyaman.edu.tr

DOI: https://doi.org/10.15345/iojes.2020.03.007 
young people (Yalçın Irmak and Erdoğan, 2016). In fact, both digital games and traditional games show similarity in terms of definition and structural features of the game concept. The points they distinguish are the playing areas of the games, the tools and equipment used in the games, the shape and contents of the games, and the number of people playing the game (Hazar et al. 2017). Various definitions are made for traditional and digital game concepts. Traditional games; It has an important place in the participants' physical, emotional, mental and social development. These games based on communication, physical ability and creativity of players. For digital game; they are games that interact with computer software with rules and objectives. The digital game industry started with the introduction of Computer Space, one of the digital games, in 1971 as the first commercial game in the industry, and has reached over a billion participants today. It has a big slice in the world media pie with a budget of $\$ 24.75$ billion (Entertainment Software Association 2013). While Atari, the first game company in the USA, has $80 \%$ of the game market, Japan, which developed the second generation console game "Space Invaders" in 1978, entered the game market (Yilmaz \& Çağıltay, 2004).

The rapid growth after the nineties in the game industry has led to the formation of digital games of different types and fast consumption. While the digital game industry in the world reached these developments explained above, the game called Corridor which translated from a foreign game into Turkish by Hakan Nehir is the first digital game in Turkey. The game named Pusu, completed in 2005 with the support of a technology company called Yogurt Technologies, is the first domestic digital game. Yalçın Irmak and Erdoğan (2016) stated that Rollings (2006) has determined seven types of games: tactics, puzzles, adventure, action, sports, role-playing and simulation. However, today, it is possible to come across many and different types of games for the players' preferences.

In addition to contributing to the development of emotional, social and cognitive aspects of people's, digital games also improve people's abilities such as hand-eye coordination and multitasking behavior (Lin and Hou, 2015). Apart from these benefits, it improves people's predictive skills and acquires resource management and reasoning skills. In addition, it enables the ability to read maps and also find direction, improve the ability of players to analyze, develop decision-making skills by reasoning logic, and even enable players to analyze, develop complex learning, thinking and application skills (Dinç, 2012; Kim and Smith, 2015; Gür, 2018). Thus, digital games are not entirely harmful, they contribute to individuals in many different ways with conscious use, but also cause some problems as a result of unconscious use. For this reason, while the limitation of the time to play digital games will enable them to gain such positive behaviors, the absence of any restrictions can cause disruption in social relations, violence, neglect of responsibility, mental and psychological disorders and physical discomfort (Toran, et al., 2016). In addition, digital games are considered as the factors that may cause more addiction time and more time for the emotions that creates in individuals due to some features. In the literature, it has been found that there are elements that motivate players in digital games and they classify them got caught up to game, socializing and success. It is also seen that these classifications are also reclassified. The success component is classified as Promotion / Progress, mechanics, social component as competition, socialization, relationship, teamwork, discovery, role play, privatization and control, and escape from reality (Yee, 2006).

\section{Materials and Methods:}

In the study, a general scanning model, one of the scanning models, was used to collect data. The general search model is one of the methods used when the universe consists of many elements and when a wider judgment about the universe is desired. In this method, the whole of the universe or a group to be taken from the universe or the scanning arrangements made on the sample. 


\section{Population and Sample}

The universe of research consists of schools that carry out high school education and training activities in Adiyaman. The sample group consists of sports high school students in the 2019-2020 academic year. The universe of the research is 320 students who continue their education in sports high school. The sample consists of 187 men and 90 women in total, 277 students. A total of 277 students participated in the research.

\section{Data Collection Tool}

The Digital Game Addiction Scale (DOBÖ-21) was developed by Lemmens et al. (2009) in order to determine problematic digital game behaviors of adolescents and consists of 21 items and seven subdimensions. In this study, The short form of the (DOBÖ-21) called (DOBÖ-7) which include seven item was used to collect data. Turkish validity and reliability study of (DOBÖ-7) was performed by Hazar and Hazar (2019). Scale is a 5-point Likert type and the scale scored as 1 is equal to never and 5 is equal to always. The lowest score that can be obtained from the scale is 7 and the highest score is 35. Hazal and Hazal (2019) determined the total Cronbach alpha value of the scale as 0.73 .

\section{Data Analysis}

SPSS 15.0 statistics program was used to evaluate the study data. In the research data, the KolmogorovSmirnov (K-S) test, which is the normality test, was performed and parametric tests were used in the analysis of the data by seeing that the data showed a normal distribution. Significance level was accepted as $\mathrm{p}<0.05$.

\section{Findings}

In this section, the findings and comments of the students constituting the research for the examination of digital game addiction levels are given. Table 1 shows the data regarding the demographic information of the students participating in the research.

Table 1. Descriptive Characteristics of the Research Group $(n=277)$

\begin{tabular}{llll}
\hline Variables & & $\boldsymbol{n}$ & $\boldsymbol{\%}$ \\
\hline \multirow{2}{*}{ Gender } & Female & 90 & 32,5 \\
& Male & 187 & 67,5 \\
\hline \multirow{4}{*}{ Age } & 14 & 54 & 19,5 \\
& 15 & 72 & 26,0 \\
& 16 & 57 & 20,6 \\
& 17 & 59 & 21,3 \\
How many hours a day & $1-2$ hour & 35 & 12,6 \\
you play digital games & $3-4$ hour & 49 & 17,3 \\
& $4-5$ hour & 67 & 22,0 \\
& 6 and above & 52 & 17,7 \\
\hline \multirow{4}{*}{ Which Material Do You } & Tablet & 148 & 53,4 \\
Use When Playing & Computer & 18 & 6,5 \\
Digital Games & Other & 25 & 13,4 \\
& I don't use & 49 & 9,0 \\
\hline
\end{tabular}

When the table is analyzed, we can see that the majority of the research group consists of 187 male students, those who play digital games for 4-5 hours at most, and that most phone materials are used while playing digital games. 
Table 2 shows the score values of the digital game addiction scale and its sub-dimensions.

Table 2. Research group's digital game addiction scale and its sub-dimensions $\bar{x}$, Min, Max values $(\mathrm{n}=277)$

\begin{tabular}{lcccc}
\hline \multicolumn{1}{c}{ Variables } & $\overline{\boldsymbol{x}}$ & Std. & Min. & Max. \\
\hline Digital Game Addiction Scale & 68,68 & 16,40 & 21,00 & 105,00 \\
Over Focus and Postponement Sub-Dimension & 40,51 & 12,01 & 11,00 & 55,00 \\
Deprivation and Quest Sub-Dimension & 19,07 & 5,12 & 6,00 & 30,00 \\
Emotion Change and Diving Sub-Dimension & 9,09 & 4,18 & 4,00 & 20,00 \\
\hline
\end{tabular}

When the Table 2 is analyzed, it is seen from the average point value that the students who participated in the research are generally addicted. When the score ranges of the sub-dimensions are examined, it is seen that the research group's score values are high in the sub-dimensions of excessive focus and procrastination and the deprivation and search sub-dimensions. However, we can see that the point value of emotion change and diving sub-dimension is low with the help of a table.

Table 3 gives the results of the analysis to determine whether there is a significant difference in the gender variable and digital game addiction scale and sub-dimensions of the research group.

Table 3. Test results of digital game addiction levels according to the gender category of the research group

\begin{tabular}{|c|c|c|c|c|c|c|c|}
\hline Dimensions & Gender & $\mathbf{n}$ & $\bar{x}$ & Std & $\mathbf{t}$ & df & $\mathrm{p}$ \\
\hline \multirow{2}{*}{ Digital Game Addiction Scale } & Female & 90 & 63,86 & 15,70 & \multirow{2}{*}{$-3,45$} & \multirow{2}{*}{275} & \multirow{2}{*}{, 00 } \\
\hline & Male & 187 & 71,00 & 16,26 & & & \\
\hline \multirow{2}{*}{$\begin{array}{l}\text { Over Focus and } \\
\text { Postponement Sub-Dimension }\end{array}$} & Female & 90 & 37,13 & 11,91 & \multirow{2}{*}{$-3,310$} & \multirow{2}{*}{275} & \multirow{2}{*}{,00 } \\
\hline & Male & 187 & 42,14 & 11,74 & & & \\
\hline \multirow{2}{*}{$\begin{array}{l}\text { Deprivation and Quest Sub- } \\
\text { Dimension }\end{array}$} & Female & 90 & 18,05 & 5,07 & \multirow{2}{*}{$-2,319$} & \multirow{2}{*}{275} & \multirow{2}{*}{,02 } \\
\hline & Male & 187 & 19,56 & 5,08 & & & \\
\hline \multirow{2}{*}{$\begin{array}{l}\text { Emotion Change and Diving } \\
\text { Sub-Dimension }\end{array}$} & Female & 90 & 8,67 & 4,27 & \multirow{2}{*}{$-1,139$} & \multirow{2}{*}{275} & \multirow{2}{*}{256} \\
\hline & Male & 187 & 9,28 & 4,13 & & & \\
\hline
\end{tabular}

Significant differences were found in gender factor, digital game addiction scale, over-focus and procrastination sub-dimension, and deprivation and search sub-dimensions $(\mathrm{p}<0.05)$. When we look at which group this significant difference results in, we see that male students play more digital games than female students.

Table 4 gives the results of the analysis to determine the difference between the age variable of the students participating in the research and the digital game addiction scale. 
Table 4. Test results of digital game addiction levels by age group of the research group

\begin{tabular}{|c|c|c|c|c|c|}
\hline Variables & $\mathbf{n}$ & & Average & \multicolumn{2}{|c|}{ Std. } \\
\hline 14 & 54 & & 72,5185 & \multicolumn{2}{|c|}{12,65469} \\
\hline 15 & 72 & & 69,3750 & \multicolumn{2}{|c|}{14,68969} \\
\hline 16 & 57 & & 65,4737 & \multicolumn{2}{|c|}{19,77562} \\
\hline 17 & 59 & & 68,8475 & \multicolumn{2}{|c|}{16,37577} \\
\hline 18 & 35 & & 66,2857 & \multicolumn{2}{|c|}{18,31517} \\
\hline \multicolumn{6}{|c|}{ Variance Analysis } \\
\hline Source & $\begin{array}{c}\text { Sum of } \\
\text { squares }\end{array}$ & Std. & $\begin{array}{c}\text { Average } \\
\text { square }\end{array}$ & $\mathbf{F}$ & p \\
\hline Intergroups & 1618,706 & 4 & 404,677 & & \\
\hline In-groups & 72667,337 & 272 & 267,159 & 1,515 & 198 \\
\hline Total & 74286,043 & 276 & & & \\
\hline
\end{tabular}

There were no significant differences between digital game addiction level and age variable $(p>0.05)$.

Table 5 presents the results of the analysis conducted to determine the difference between the variable of how many hours a day the digital group plays, and the digital game addiction scale and its sub-dimensions.

Table 5. Test results of the digital game addiction levels of the research group according to the number of hours of digital games you play per day

\begin{tabular}{|c|c|c|c|c|c|}
\hline & Variables & $\mathrm{n}$ & Average & & td. \\
\hline \multirow{5}{*}{$\begin{array}{l}\text { Digital Game Addiction } \\
\text { Scale }\end{array}$} & Not playing & 48 & 62,04 & & 28 \\
\hline & 1-2 hour & 61 & 72,18 & & 08 \\
\hline & 3-4 hour & 49 & 69,61 & & 70 \\
\hline & 4-5 hour & 67 & 66,56 & & 90 \\
\hline & 6 hour and above & 52 & 72,55 & & ,73 \\
\hline \multirow{5}{*}{$\begin{array}{l}\text { Over Focus and } \\
\text { Postponement Sub- } \\
\text { Dimension }\end{array}$} & Not playing & 48 & 43,00 & &, 55 \\
\hline & 1-2 hour & 61 & 39,48 & &, 65 \\
\hline & 3-4 hour & 49 & 39,26 & & 44 \\
\hline & 4-5 hour & 67 & 42,84 & & ,57 \\
\hline & 6 hour and above & 52 & 37,62 & & ,70 \\
\hline \multirow{5}{*}{$\begin{array}{l}\text { Deprivation and Quest } \\
\text { Sub-Dimension }\end{array}$} & Not playing & 48 & 19,90 & & 77 \\
\hline & 1-2 hour & 61 & 19,85 & & 22 \\
\hline & 3-4 hour & 49 & 18,47 & & 90 \\
\hline & 4-5 hour & 67 & 20,13 & & 81 \\
\hline & 6 hour and above & 52 & 16,91 & & 95 \\
\hline \multirow{7}{*}{$\begin{array}{l}\text { Emotion Change and } \\
\text { Diving Sub-Dimension }\end{array}$} & Not playing & 48 & 9,27 & & 23 \\
\hline & 1-2 hour & 61 & 10,26 & & 55 \\
\hline & 3-4 hour & 49 & 8,82 & & 73 \\
\hline & 4-5 hour & 67 & 9,57 & & 42 \\
\hline & 6 hour and above & 52 & 7,50 & & 66 \\
\hline & \multicolumn{5}{|c|}{ Variance Analysis } \\
\hline & Source & $\begin{array}{l}\text { Sum of } \\
\text { squares }\end{array}$ & $\begin{array}{cc}\text { Average } \\
\text { Std. }\end{array} \begin{array}{c}\text { square } \\
\text { squa }\end{array}$ & $\mathbf{F}$ & p \\
\hline \multirow{4}{*}{$\begin{array}{l}\text { Digital Game } \\
\text { Addiction Scale }\end{array}$} & Intergroups & 3986,203 & 996,55 & & \\
\hline & In-groups & 0299,840 & 258,45 & 3,85 & ,00 \\
\hline & Total & 4286,043 & 276 & & \\
\hline & Intergroups & 215,749 & 303,937 & 2,142 & ,07 \\
\hline
\end{tabular}




\begin{tabular}{lclllll} 
Over Focus and & In-groups & 38603,428 & 272 & 141,924 & & \\
$\begin{array}{l}\text { Postponement Sub- } \\
\text { Dimension }\end{array}$ & Total & 39819,177 & 276 & & & \\
\hline \multirow{2}{*}{$\begin{array}{l}\text { Deprivation and } \\
\text { Quest Sub-Dimension }\end{array}$} & Intergroups & 377,557 & 4 & 94,389 & & \\
& Total & 7237,408 & 276 & & & \\
\hline Emotion Change and & Intergroups & 208,387 & 4 & 52,097 & & \\
Diving Sub- & In-groups & 4624,356 & 272 & 17,001 & 3,064 & \multirow{2}{*}{01} \\
Dimension & Total & 4832,744 & 276 & & & \\
\hline
\end{tabular}

When Table 5 is analyzed, significant differences were found between students' digital game play times and sub-dimensions called digital game addiction scale, deprivation and search subscale, emotion change and diving ( $\mathrm{p}<0.05$ ). When we look at which groups this significant difference resulted in favor, it was seen that those who play digital games with a digital game addiction scale between 1-2 hours a day and 6 and above and those who don't play. In addition, it was observed that the sub-dimension of deprivation and search was between those who did not play and those who played 1-2 hours a day, 3-4 hours a day and 6 hours or more. In the sub-dimension of emotion change and diving, it was observed that it was between those who did not play and the group who stated that they played digital games 3-4 hours a day.

In Table 6, the results of the analysis made to determine the relationship between the materials used by the students participating in the study and the digital game addiction scale are given.

Table 6. Test results of digital game addiction levels according to the category of materials used by the research group while playing digital games

\begin{tabular}{|c|c|c|c|c|c|}
\hline \multicolumn{2}{|c|}{ Variables } & \multicolumn{2}{|r|}{$\mathbf{n}$} & \multirow{2}{*}{$\begin{array}{c}\text { Average } \\
70,59\end{array}$} & \multirow{2}{*}{$\begin{array}{r}\text { Std. } \\
15,47\end{array}$} \\
\hline Phone $^{1}$ & & & 148 & & \\
\hline Tablet $^{2}$ & & & 18 & 63,83 & 13,24 \\
\hline Compouter ${ }^{3}$ & & & 37 & 70,05 & 16,81 \\
\hline Other ${ }^{4}$ & & & 25 & 59,68 & 19,76 \\
\hline Not Using 5 & & & 49 & 68,24 & 16,74 \\
\hline \multicolumn{6}{|c|}{ Variance Analysis } \\
\hline Source & $\begin{array}{l}\text { Sum of } \\
\text { squares }\end{array}$ & Std. & $\begin{array}{c}\text { Average } \\
\text { square }\end{array}$ & $\mathbf{F}$ & $\mathrm{p}$ \\
\hline Intergroups & 3069,475 & 4 & 767,36 & & \\
\hline In-groups & 71216,569 & 272 & 261,82 & 2,93 & ,02 \\
\hline Total & 74286,043 & 276 & & & \\
\hline
\end{tabular}

When the table was examined, a significant difference was found between the material used and the scale $(p<0.05)$. We see that this group of significant differences is in favor of those who play the digital game on the phone when we sunk in between the phone and other options.

\section{Results and Discussion:}

In this section, the results of the findings related to examining the digital game addiction levels of sports high school students are tried to be discussed by considering similar studies.

In the table, which contains demographic information of the students participating in the research, it is seen that male students with 187 attendance, 72 people with 15 age groups stand out with the highest participation. In addition, it is seen that 67 people play $4-5$ hours of digital games and 148 people use the most phone material while playing digital games (see Table 1). 
When the scores of the students forming the research from the digital game addiction scale are examined, the average score of the participants is 68.68. This shows that participants' high levels of digital game addiction are high. When the sub-dimensions of the scale were analyzed, it was observed that the participants' over-focus and procrastination (avg: 40.51) and deprivation and seeking (avg: 19.07) subdimensions were high. However, it was concluded that the sub-dimension of emotion change and diving (avg: 9.09) was low (Table 2).

In some scientific research results, it is stated that children exposed to a lot of digital games are physiologically affected. They list these effects as dry eye, personal care and disruption, carpal tunnel syndrome, irregular nutrition, and headache and back pain (Griffiths and Meredith, 2009).

In the literature, it is stated in the studies on digital games that the social skills of children are related to the duration of digital games, and with the increase in the duration of digital games, the social skills of children will decrease and even the child will experience problems between virtual and real playgrounds. In addition, it is stated that these children will be exposed to physical fatigue very much and they will experience communication and harmony with the group they are in (Gürcan, Özhan \& Uslu, 2008; Kerckaert, Vanderlinde, and van Braak, 2015; Egemen, Y1lmaz and Akil, 2004; Tuğrul, Ertürk, Özen, Güneş and 2014). Braun et al. (2016) stated that high level of addiction in action games, which is one of the digital game categories, creates a high level of extraversion and low level neuroticism features.

The t-test was conducted to determine the difference between the digital game addiction levels of the research group and the gender factor. As a result of the test, significant differences were found between the gender factor and the digital game addiction scale, the over-focus and procrastination sub-dimension, and the deprivation and search sub-dimensions $(\mathrm{p}<0.05)$. Considering which group this significant difference resulted in favor, it is seen that male students play more digital games than female students (Table 3). This is mainly due to the fact that the content of digital games appeals to men more than women. Because when the studies investigating the preference order of digital games are examined, it is seen that PUBG, GTA, League of Legends, Clash Royale, Counter Strike, Zula are the most action games. When looking at the content of these games, it was seen that the mentioned games were armed, online and multiplayer (Taylan, Kara \& Durgun, 2017). Torres-Rodriguez et al. (2018) concluded that participants' online game addiction levels were high in their studies on male individuals. They also stated that these people were exposed to high stress in their living conditions, as well as their characteristics, such as obsessive-compulsive tendencies, introversion, interpersonal sensitivity, frustration, surrender tendency, phobic anxiety and hostility, and related to the level of online game addiction.

In order to determine the difference between the age variable of the group constituting the study and the digital game addiction scale, no significant differences were found (Table 4). In the studies conducted about this topic, they stated that the age of digital gaming decreases day by day, as well as the level of addiction also increases (Toran et al. 2016; Demirtaş and Çakılcı 2014; Karagöz 2019).

ANOVA test was performed in order to determine the difference between how many hours of digital games students participate in the study and the digital game addiction scale. As a result of the ANOVA test, significant differences were found between digital game play times and digital game addiction scale, deprivation and quest sub-dimension, emotion change and diving sub-dimensions. When we look at which groups this significant difference resulted in favor, it was seen that digital game addiction scale is between those who play digital games 1-2 hours a day and 6 hours or more and those who don't play. In addition, we see that it is between those who do not play in the sub-dimension of deprivation and seeking, and those who play 1-2 hours a day, 3-4 hours and 6 or more hours, and those who do not play in the emotional change and dive sub-dimension, and that they play digital games 3-4 hours a day ( Table 5). In the group that constitutes the research, it is seen that the average scores of those who play digital games 6 hours or more per day are 
high and their digital game addiction levels are high. When we calculate the average time zone that these people play weekly, we see that it corresponds to 42 hours. In their study, Wan and Chiou (2006) stated that the time spent in digital games per week is 41 hours, indicating that these people have high levels of addiction. This result supports the results of our study.

When the studies on digital games are examined in the literature, it is seen that it provides an increase in the level of addiction in parallel with the increase in the duration of digital game play. In other words, according to these studies, it is the right ratio between digital game playing time and addiction (Blinka \& Mikuska, 2014; Lewis, 2016; Derin \& Bilge, 2016; Gökçearslan \& Günbatar, 2012; Karagöz, 2019; Nalwa \& Anand, 2003). In addition, it is found in studies that conclude that the feeling of loneliness in individuals increased with the increase in digital game play time (Mustafaoğlu \& Yasac1, 2018; Gürgan, Karaman \& Milas, 2018).

Significant differences were found as a result of the ANOVA test conducted to determine the difference between the material variable used by the group constituting the research and the digital game addiction scale. When looking at which group these significant differences resulted in favor, it is seen that it is between the phone and other options and resulted in favor of those who play the digital game from the phone (see Table $6)$.

When the results of the studies on the subject are examined in the literature, it is seen that the phone is preferred as a game tool (Köse, 2013; Yiğit, 2017; Ceylaner and Yanpar Yelken, 2017; Dursun and EraslanÇapan, 2018; Balıkçı, 2018). Due to the fact that the phone material is accessible to any game with an internet connection and is ready for use at any time, it is difficult to control which game and how long the person has played. In their study, Bülbül and Tunç (2018) stated that people who have smartphones at an early age also have high levels of addiction. Within the framework of this result, it can be said that one of the reasons that increase addiction is to have a smartphone. Additionally, As explained above, the time spent by people in digital games per week is 41 hours, indicating that their addiction levels are high (Wan \& Chiou, 2006). During the Covid 19 period, people try to stay at home and spend more time at home. This situation increase the tendency of spending more time by playing digital games and this fact may yields to increase the digital game addiction levels of these people. To avoid from this risk, in accordance with current work, people should limit their playing time under the critical value defined above. 


\section{REFERENCES}

Balıkçı, R. (2018). Çocuklarda ve ergenlerde çevrimiçi oyun bağımlılı̆̆ı ve agresif davranışlar arasındaki ilişkinin incelenmesi. (Unpublished MSc Thesis) Fatih Sultan Mehmet University, Social Sciences Institutes.

Binark, M., \& Bayraktutan-Sütcü, G. (2008). Kültür endüstrisi ürünü olarak dijital oyun. Kalkedon Yayınevi: İstanbul pp.221.

Blinka, L., \& Mikuška, J. (2014). The role of social motivation and sociability of gamers in online game addiction. Cyberpsychology: Journal of Psychosocial Research on Cyberspace 8(2), 1-10.

Braun, B., \& et al. (2016). Personality and video gaming: Comparing regular gamers, non-gamers, and gaming addicts and differentiating between game genres. Computers in Human Behavior, 55, 406-412.

Bülbül, H., \& Tunç, T. (2018). Telefon ve oyun bağımlılı̆̆ı: ölçek incelemesi, başlama yaşı ve başarıyla ilişkisi. Süleyman Demirel Üniversitesi Vizyoner Dergisi, 9(21), 1-13.

Ceylaner, S., \& Yanpar Yelken, T. (2017). Ortaöğretim öğrencilerinin, dijital oyunların İngilizce kelime öğrenimine katkısına yönelik görüşleri. Bartın Üniversitesi Ĕ̆itim Fakültesi Dergisi, 6(1), 346-364.

Demirtaş Madran, H. A., \& Ferigül Çakılcı, E. (2014). Çok oyunculu çevrimiçi video oyunu oynayan bireylerde video oyunu bağımlılığı ve saldırganlık. Anadolu Psikiyatri Dergisi, 15, 99-107.

Derin, S., \& Bilge, F. (2016). Ergenlerde İnternet bağımlılığı ve öznel iyi oluş düzeyi. Türk Psikolojik Danışma ve Rehberlik Dergisi, 6(46), 35-51.

Dinç, M .(2012). Türkiye Dijital Oyunlar Federasyonu, Erişim tarihi: 01.04.2016 https://www.tbmm.gov.tr/ arastirma_komisyonlari/bilisim_internet/docs/sunumlar/turkiye_dijital_oyunlar_federasyonu.pdf

Dursun, A., \& Eraslan-Çapan, B. (2018). Digital game addiction and psychological needs for teeanergers. Inonu University Journal of the Faculty of Education, 19(2), 128-140.

Egemen, A., Yılmaz, Ö., \& Akil, İ. (2004). Oyun, oyuncak ve çocuk. ADÜ Tıp Fakültesi, 5(2), 39-42.

Entertainment Software Association. (2013). Essential Facts About Computer and Video Industry 2012. Washington D.C, USA: Entertainment Software Association.

Gentile, D. (2009). Pathological video game use among youth 8 to 18: A national. Psychol Sci, 20(5), 594-602.

Gökçearslan, Ş., \& Günbatar, M. S. (2012). Ortaöğrenim öğrencilerinde İnternet bağımlılı̆̆ı. Ĕ̆itim Teknolojisi Kuram ve Uygulama, 2(2), 10-24.

Griffiths, M. D., \& Meredith, A. (2009). Videogame addiction and its treatment. Journal of Contemporary Psychotherapy, 39, 247-253.

Gür, R. M. (2018). Çok oyunculu dijital oyunlarda oyun oynama pratikleri: Moba ve mmorpg oyunlar üzerine karşılaştırmalı bir inceleme. (Unpublished MSc Thesis) İstanbul Arel University, Social Sciences Institutes: İstanbul

Gürcan, A., Özhan, S., \& Uslu, R. (2008). Dijital oyunlar ve çocuklar üzerindeki etkileri. Başbakanlık Aile ve Sosyal Araştırmalar Genel Müdürlüğü Yayınları: Ankara.

Gürgan, U., Karaman, B., \& Minaz, B. (2018). 14-24 yaş arası öğrencilerde sosyal ve duygusal yalnızlığın oyun bağımlılığı ile ilişkisi. Uluslararası Necatibey Eğitim ve Sosyal Bilimler Araştırmaları Kongresi, (s. 303-356). Ankara. 
Hazar, Z., Tekkurşun Demir, G., \& Dalkıran, H. (2017). Ortaokul Öğrencilerinin Geleneksel Oyun Ve Dijital Oyun Algılarının İncelenmesi: Karşılaştırmalı Metafor Çalışması. Spormetre Beden Ĕ̆itimi ve Spor Bilimleri Dergisi, 15(4), 179-190.

Karagöz, D. B. (2019). İnternet bağımlılığı ve bilgisayar oyun bağımlılı̆̆ı yaygınlığının, ilişkili etkenlerin incelenmesi. Yükseköğretim Kurulu Ulusal Tez Merkezi'nden edinilmiştir.

Karasar, N. (2005). Bilimsel Araştırma Yöntemi. Nobel yayın ve dağıtım: Ankara

Kerckaert, S., Vanderlinde, R., \& van Braak, J. (2015). The role of ICT in early childhood education: Scale development and research on ICT use and influencing factors. European Early Childhood Education Research Journal, 23(2), 183-199.

Kim, Y., \& Smith, D. (2015). Pedagogical and technological augmentation of mobile learning for young children interactive learning environments. Interactive Learning Environments, 25(1), 1-13.

Köse, Z. (2013). 13-14 yaş grubu ergenlerin bilgisayar oyunlarını oynama alışkanlıklarının ve sosyalleşme durumlarının araştırılması. (Unpublished MSc Thesis) Afyon Kocatepe University, Social Sciences Institutes.

Lewis, M. S. (2016). Massively multiplayer online roleplaying gaming: Motivation to play, player typologies, and addiction (Unpublished PhD thesis). Available on: https://etd.ohiolink.edu/pg_10?0:: NO:10:P10_ ACCESSION_NUM:osu1461232700

Lemmens JS, Valkenburg PM, Peter J. (2009). Development and validation of a game addiction scale for adolescents. Media Psychology, 12, 77-95.

Lin, Y. H., \& Hou, H. T. (2015). Exploring young children's performance on and acceptance of an educational scenario-based digital game for teaching route-planning strategies: a case study. Interactive Learning Environments, 24(8), 1967-1980.

Mustafaoğlu, R., \& Yasacı, Z. (2018). Dijital oyun oynamanın çocukların ruhsal ve fiziksel sağlı̆̆ı üzerine olumsuz etkileri. Bă̆̆mlılık Dergisi, 19(3), 51-58.

Nalwa, K., \& Anand, A. P. (2003). İnternet addiction in students: a cause of concern. Cyberpsychology Behavior, 6(6), 653-656.

Rideout, V., Foehr, U., \& Roberts, D. (2010). Generation M2: Media in the lives. Kaiser Family Foundation.

Taylan, H. H., Kara, H. Z., \& Durğun, A. (2017). Ortaokul ve lise öğrencilerinin bilgisayar oyunu oynama alışkanlıkları ve oyun tercihleri üzerine bir araştırma. Pesa Uluslararası Sosyal Araştırmalar Dergisi, 3(1), 78-87.

Toran, M., Ulusoy, Z., Aydın, B., Deveci, T., \& Akbulut, A. (2016). Çocukların dijital oyun kullanımına ilişkin annelerin görüşlerinin değerlendirilmesi. Kastamonu Eğitim Dergisi 24(5), 2263-2278.

Torres-Rodríguez, A., Griffiths, M. D., Carbonell, X., \& Oberst, U. (2018). Internet gaming disorder in adolescence: Psychological characteristics of a clinical sample. Journal of Behavioral Addictions, 7(3), 707718.

Torun, F., Akçay, A., \& Çoklar, A. N. (2015). Bilgisayar oyunlarının ortaokul öğrencilerinin akademik davranış ve sosyal yaşam üzerine etkilerinin incelenmesi. Karaelmas Journal of Education, 3(1), 25-35.

Tuğrul, B., Ertürk, G., Özen, Ş., \& Güneş, G. (2014). Oyunun üç kuşaktaki değişimi. The Journal of Academic Social Science Studies, 27, 1-16. 
Wan, C. S., \& Chiou, W. B. (2013). Ergenler İnternet oyunlarına neden bağımlılar: Tayvan'da bir mülakat çalışması. Toplum Bilimleri Dergisi, 7(14), 411-418.

Yalçın Irmak, a. (2016). Ergen ve Genç Erişkinlerde Dijital Oyun Bağımlılı̆̆ı:Güncel Bir Bakış. Türk Psikiyatri Dergisi, 27(2), 128-137.

Yee, N. (2006). Motivations For Play In Online Games. Cyberpsychol Behav 9(6), 772-775.

Yiğit, E. (2017). Çocukların dijital oyun bağımlılığında ailelerin bazı değişkenler açısından incelenmesi. (Unpublished MSc Thesis) Yüzüncüyıl University, Educational Sciences Institutes, Van.

Yılmaz, E., \& Çağıltay, K. (2004). Bilişim Teknolojileri Işı̆̆ında Eğitim Konferansı. Elektronik oyunlar ve Türkiye. Ankara. 